\title{
KAJIAN PENGELOLAAN BISNIS USAHATANI TERPADU DI JALAN BOULEVARD TONDANO
}

\author{
Maryo Lussy Grace Sumangkut \\ Jolanda Kitsia Juliana Kalangi \\ Wenny Tilaar
}

\begin{tabular}{ll}
\hline Naskah diterima melalui Email agrisosioekonomi@unsrat.ac.id & : Kamis, 23 Juli 2020 \\
Disetujui diterbitkan & : Sabtu, 25 Juli 2020 \\
\hline
\end{tabular}

\begin{abstract}
This study aims to determine the integrated farming business management on Tondano Boulevard Road, which involves 1) the ability to increase household income; 2) ability to reduce the risk of crop failure; 3) the ability to provide additional employment for families; 4) the ability to improve the efficiency of resource use; 5) ability to provide food for families; 6) ability to increase land productivity; and 7) the ability to improve the welfare of farm households. This research was carried out in November 2019 to February 2020 in the Tondano Boulevard Farming Business Area in Koya Village, South Tondano Sibdistrict. This study used qualitative research methods. Data collected through interviews, direct observations, document studies, and literature studies. Interviews and observations were made on informants namely farmers and village government as many as 10 people who were chosen purposively. Document studies include Minahasa in Figures 2018 and literature studies including journal articles. This research used qualitative data analysis. The results showed that the Integrated Farming Business Management on Tondano Boulevard Road was quite optimal including 1) able to increase the income of farmer households, namely farmers doing farming by planting rice, some were raising livestock and there were farmers who used part of their land to open a restaurant business, or rent out part of his farm to become a restaurant. 2) able to reduce the risk of crop failure through various businesses such as raising livestock, using part of the land for a place of business and renting part of the land as a place of business so that it can reduce the risk if there is no income due to crop failure. 3) able to provide additional employment for farming families, namely farmers who own agricultural land on Tondano Boulevard Road, in addition to being farmers who take care of their fields, they also have additional businesses such as raising livestock and use some of their land as a place of business such as restaurants. The existence of a side business has created job opportunities. 4) able to improve the efficient use of resources, namely farmers who utilize all available resources, energy, machinery and water that make rice planted will produce higher quality of rice. 5) enables farmers to provide food for their families, namely farmers who have agricultural land on Tondano Boulevard Road, most of them have enough income to provide food for their families. 6) able to increase land productivity that is able to manage their farming so that land productivity and farmers' income will increase. 7) able to improve the welfare of farmers' households. that is, farmers are able to meet their clothing needs, are able to obtain adequate housing, are able to access health services, and are able to gain access to education. ${ }^{*}$ eprm*
\end{abstract}

Keywords: integrated farming business management, income, employment, farmers household welfare 


\begin{abstract}
ABSTRAK
Penelitian ini bertujuan untuk mengetahui pengelolaan bisnis usahatani terpadu di Jalan Boulevard Tondano yaitu menyangkut 1) kemampuan meningkatkan pendapatan rumah tangga; 2) kemampuan mengurangi risiko kegagalan panen; 3) kemampuan memberikan tambahan lapangan kerja bagi keluarga; 4) kemampuan meningkatkan efisiensi pengunaan sumberdaya; 5) kemampuan menyediakan pangan bagi keluarga; 6) kemampuan meningkatkan produktivitas lahan; dan 7) kemampuan memperbaiki kesejahteraan rumah tangga petani. Penelitian ini dilaksanakan pada bulan November 2019 sampai Februari 2020 di Kawasan Bisnis Usahatani Jalan Boulevard Tondano di Desa Koya, Kecamatan Tondano Selatan. Penelitian ini menggunakan metode penelitian kualitatif. Data yang dikumpulkan melalui wawancara, pengamatan langsung, studi dokumen, dan studi kepustakaan. Wawancara dan pengamatan dilakukan pada informan yaitu petani dan pemerintah desa sebanyak 10 orang yang dipilih secara sengaja (purposive sampling). Studi dokumen antara lain Minahasa dalam Angka 2018 dan studi kepustakaan antara lain artikel jurnal. Penelitian ini menggunakan analisis data kualitatif. Hasil penelitian menunjukkan bahwa Pengelolaan Bisnis Usahatani Terpadu di Jalan Boulevard Tondano sudah cukup optimal diantaranya 1) mampu meningkatkan pendapatan rumah tangga petani yaitu petani melakukan usahatani lewat menanam padi, ada juga yang memelihara ternak dan ada petani yang menggunakan sebagian lahannya untuk membuka usaha rumah makan, ataupun menyewakan sebagian lahan pertaniannya untuk dijadikan rumah makan. 2) mampu mengurangi resiko kegagalan panen yaitu melalui berbagai usaha seperti beternak, menggunakan sebagian lahan untuk tempat usaha serta menyewakan sebagian lahan sebagai tempat usaha maka akan dapat mengurangi resiko bila terjadi tidak adanya penghasilan karena gagal panen. 3) mampu memberikan tambahan lapangan kerja bagi keluarga petani yaitu petani yang memiliki lahan pertanian di Jalan Boulevard Tondano umumnya selain menjadi petani yang mengurusi sawah mereka juga memiliki tambahan usaha lain seperti beternak dan menggunakan sebagian lahan yang mereka punya sebagai tempat usaha seperti rumah makan. Adanya usaha sampingan telah menciptakan lapangan pekerjaan. 4) mampu meningkatkan efisiensi penggunaan sumberdaya yaitu petani yang memanfaatkan semua sumberdaya yang ada baik, tenaga, mesin maupun air yang membuat tanaman padi yang ditanam akan menghasilkan padi yang berkualitas. 5) memampukan petani menyediakan pangan bagi keluarga yaitu petani yang memiliki lahan pertanian di Jalan Boulevard Tondano kebanyakan mempunyai pendapatan yang cukup untuk menyediakan pangan bagi keluargannya.6) mampu meningkatkan produktifitas lahan.yaitu peningkatan produktivitas lahan merupakan tanda bahwa petani sudah mampu mengelola lahan petani semakin mampu mengelola usahataninya sehingga produktifitas lahan dan pendapatan petani pun akan semakin meningkat. 7) mampu memperbaiki kesejahteraan rumah tangga petani.yaitu petani mampu untuk memenuhi kebutuhan sandangnya, mampu untuk memperoleh perumahan yang layak, mampu mengakses pelayanan kesehatan, serta mampu memperoleh akses terhadap pendidikan. ${ }^{*}$ eprm*
\end{abstract}

Kata kunci : pendapatan, lapangan pekerjaan, kesejahteraan rumah tangga petani

\section{PENDAHULUAN}

Latar Belakang

Pertanian merupakan basis utama perekonomian di Indonesia. Masyarakat Indonesia sebagian besar masih menggantung-kan hidupnya pada sektor pertanian. Alasan inilah mengapa pemerintah memberikan perhatian khusus untuk sektor pertanian salah satunya yaitu peningkatan produksi padi. Namun dalam peningkatan produksi padi, pemerintah menghadapi berbagai kendala baik yang bersifat teknis maupun non teknis seperti penurunan kesuburan tanah, keterbatasanlahan, alih fungsi lahan dan permasalahan lainnya. Alih fungsi lahan merupakan kendala terbesar yang sedang dihadapi pemerintah saat ini. Di Indonesia, permasalahan alih fungsi lahan yang banyak ditemui antara lain persawahan yang berubah menjadi perumahan, begitupun dengan lahan perkebunan kelapa sawit yang sudah berubah menjadi perumahan, hal ini secara otomatis menurunkan produksi nasional. 
Tanah sawah merupakan tanah yang sangat penting di Indonesia karena merupakan sumber daya alam yang utama dalam produksi beras. Saat ini keberadaan tanah-tanah sawah subur beririgasi terancam oleh gencarnya pembangunan kawasan industri dan perluasan kota (perumahan) sehingga luas tanah sawah semakin berkurang karena dikonversikan untuk penggunaan nonpertanian. Tanah sawah adalah tanah yang digunakan untuk menanam padi sawah baik secara terus menerus sepanjang tahun maupun bergiliran dengan tanaman palawija. Dalam definisi ini tanah sawah mencakup semua tanah yang terdapat dalam zona iklim dengan rejim temperatur yang sesuai untuk menanam padi paling tidak satu kali setahun (Winoto, 2005).

Alih fungsi lahan pertanian di sepanjang Jalan Boulevard Tondano menjadi hal yang tidak dapat dihindari, hal ini dikarenakan petani dalam menjalankan usahataninya tentu berharap akan mendapatkan penerimaan yang lebih besar dari biaya produksi yang telah dikeluarkan. Tetapi kenyataannya tidak selamanya sesuai dengan harapan, bahkan tidak sedikit petani yang mengalami kerugian. Hal ini juga merupakan fenomena yang terjadi saat ini, yaitu petani terkadang mendapatkan penerimaan yang tidak sebanding dengan pengeluaran, sehingga membuat petani mencari cara lain untuk meningkatkan penghasilan. Untuk petani di kawasan jalan boulevard Tondano, cara yang mereka lakukan yaitu dengan memanfaatkan sebagian lahan pertanian menjadi tempat berbisinis. Petani berbisnis tetapi tidak meninggalkan profesi mereka, mereka hanya mengalih fungsikan sebagian lahan pertanian mereka sebagai tempat usaha, dan sebahagian besar tetap diajadikan lahan persawahan.

Pengelolaan usaha tani yang berorientasi komersial merupakan fenomena yang sekarang terjadi pada kawasan boulevard Tondano. Hal ini ditandai dengan sebahagian lahan-lahan persawahan sudah mulai dialih fungsikan restoranrestoran. Hal ini dibuktikan di sepanjang jalan boulevard Tondano ditemui restoran-restoran yang menyajikan berbagai macam menu masakan. Restoran-restoran ini dibagun pada sebagian lahan persawahan. besarnya lahan yang dijadikan lahan komersil tidak besar, hanya di pingiran lahan persawahan, akan tetapi dampak yang diberikan bagi peningkatan kesejahtreraan petani cukup besar. Hal ini dikarenakan dengan pengelolaan usaha tani yang berorientasi komersial maka pentani bisa mendapatkan penghasilan tambahan selain dari hasil sawah mereka saja.
Berdasarkan data diatas maka penulis tertarik untuk melakukan penelitian menyangkut pengelolaan bisnis usaha tani terpadu di jalan boulevard Tondano.

\section{Rumusan Masalah}

Perumusan masalah dalam penelitian ini adalah bagaimana pengelolaan bisnis usahatani terpadu di jalan boulevard Tondano menyangkut:

1) Apakah petani mampu meningkatkan pendapatan rumah tangga?

2) Apakah petani mampu mengurangi risiko kegagalan panen?

3) Apakah petani mampu memberikan tambahan lapangan kerja bagi keluarga?

4) Apakah petani mampu meningkatkan efisiensi pengunaan sumberdaya?

5) Apakah petani mampu menyediakan pangan bagi keluarga

6) Apakah petani mampu meningkatkan produktivitas lahan?

7) Apakah petani mampu memperbaiki kesejahteraan rumah tangga petani.

\section{Tujuan Penelitian}

Tujuan penelitian adalah untuk mengetahui pengelolaan bisnis usahatani terpadu di jalan boulevard Tondano yaitu menyangkut:

1) Kemapuan meningkatkan pendapatan rumah tangga.

2) Kemampuan mengurangi risiko kegagalan panen.

3) Kemampuan memberikan tambahan lapangan kerja bagi keluarga.

4) Kemampuan meningkatkan efisiensi pengunaan sumberdaya.

5) Kemampuan menyediakan pangan bagi keluarga

6) Kemampuan meningkatkan produktivitas lahan

7) Kemampuan memperbaiki kesejahteraan rumah tangga petani.

\section{Manfaat Praktis}

\section{Manfaat Penelitian}

Sebagai bahan pertimbangan yang dapat digunakan oleh pemda setempat dalam membuat kebijakan.

\section{Manfaat Akademik :}

Sebagai bahan referensi atau sumber informasi ilmiah bagi pihak-pihak yang membutuhkan. 


\section{METODE PENELITIAN}

\section{Tempat dan Waktu Penelitian}

Penelitian ini dilaksanakan selama 3 (tiga) bulan dimulai pada bulan November 2019 sampai Februari 2020 di Kawasan Bisnis Usahatani Jalan Boulevard Tondano di Desa Koya, Kecamatan Tondano Selatan.

\section{Jenis Penelitian}

Penelitian ini dilakukan dengan metode kualitiatif. Hal ini terlihat dari prosedur yang ditetapkan yaitu prosedur penelitian yang menghasilkan data deskriptif: ucapan atau tulisan dan perilaku yang diamati dari orang-orang (subjek) itu sendiri.

Menurut Moleong (2004) penelitian kualitatif adalah penelitian yang bermaksud untuk memahami fenomena tentang apa yang dialami oleh subjek penelitian misalnya perilaku, persepsi, motivasi, tindakan, dll, secara holistik dan dengan cara deskripsi dalam bentuk kata-kata dan bahasa pada suatu konteks khusus yang alamiah. Istilah penelitian kualitatif menurut Kirk dan Miler (1986 :9) adalah tradisi tertentu dalam ilmu pengetahuan sosial yang secara fundamental bergantung pada pengamatan pada manusia dalam kehasannya sendiri dan berhubungan dengan orang-orang tersebut dalam bahasa dan dalam peristilahan.

Sugiyono (2009) mengemukakan beberapa karakteristik penelitian kualitatif sebagai berikut:

1. Dilakukan pada kondisi alamiah (sebagai lawannya adalah eksperimen), langsung ke sumber data dan peneliti adalah instrument kunci.

2. Penelitian kualitatif bersikap deskriptif. Data yang terkumpul berbentuk kata-kata atau gambar, sehingga tidak menekankan pada angka.

3. Penelitian kualitatif menekankan pada proses daripada produk atau outcome.

4. Penelitian kualitatif merupakan analisis data secara induktif. Penelitian kualitatif lebih menekankan makna (data dibalik yang teramati).

Penelitian kualitatif memiliki ciri atau karakteristik yang berbeda dengan penelitian jenis lainnya (Muhajir, 2000). Pada penelitian kualitatif, penelitian tidak dimulai dengan menguji teori untuk membuktikan, melainkan sebaliknya. Dalam pendekatan kualitatif, suatu teori dapat muncul dalam proses penelitian (Creswell, 2003). Creswell menjelaskan bahwa di dalam penelitian kualitatif, pengetahuan dibangun melalui interprestasi terhadap multi perspektif yang berbagai dari masukan segenap partisipan yang terlibat di dalam penelitian, tidak hanya dari penelitinya semata. Sumber datanya bermacam-macam, seperti catatan observasi, catatan wawancara pengalaman individu, dan sejarah.

\section{Sumber data}

Penelitian ini menggunakan data kualitatif berupa hasil penelitian lapangan melalui wawancara dan observasi di Kawasan Boulevard Tondano. Wawancara yang dilakukan dengan petani, pengunjung dan pemerintah di Desa Koya Kecamatan Tondano Selatan.

Selain itu juga dilakukan studi dokumen melalui dokumen Minahasa dalam Angka 2018 serta dokumen-dokumen lain yang dirasakan penting guna menunjang penelitian. Studi kepustakaan melalui buku-buku ilmiah, laporan penelitian, jurnal, tesis, peraturan perundangundangan serta reveresni lainnya yang dianggap relevan dengan penelitian dan referensi lainnya yang berkaitan dengan objek yang diteliti.

\section{Informan penelitian}

Informan adalah orang yang berada pada lingkup penelitian, artinya merupakan orang yang dapat memberikan informasi tentang situasi dan kondisi latar penelitian. Menurut Soemanto (1995) dalam Saroinsong dkk (2012) penelitian dengan pendekatan deskriptif penentuan jumlah responden tidak ada ukuran mutlak. Informan dipilih dengan tujuan mendeskripsikan suatu gejala sosial atau masalah sosial tertentu berdasarkan pertimbangan tertentu sehingga disebut sampling bertujuan (purposive sampling). Informan dalam penelitian ini yaitu petani dan pemerintah di Desa Koya Kecamatan Tondano Selatan.

\section{Fokus penelitian}

Adapun fokus penelitian adalah bagaimana pengelolaan bisnis usaha tani terpadu di jalan boulevard Tondano. Pengelolaan bisnis usaha tani terpadu yang dimaksud yaitu alih fungsi sebagian lahan pertanian menjadi tempat usaha tanpa beralih profesi sebagai petani, dikarenakan lahan pertanian yang dialih fungsikan hanya sebahagian kecil, jadi sebahagian besar lahan pertanian tetap berfungsi sebagai lahan persawahan. Bisnis usaha tani terpadu bertujuan untuk meningkatkan kesejahteraan petani. Keuntungan dari usahatani terpadu antara lain: 1) mampu meningkatkan pendapatan rumah tangga; 2) mengurangi risiko kegagalan panen; 3) memberikan tambahan lapangan kerja bagi keluarga; 4) 
meningkatkan efisiensi pengunaan sumberdaya; 5) dapat menyediakan pangan bagi keluarga; 6) meningkatkan produktivitas lahan; dan 7) memperbaiki kesejahteraan rumah tangga petani, kesejahteraan yang dimaksud yaitu :

a. Masyarakat dapat mencukup kebutuhan sandangnya.

b. Masyarakat bisa memperoleh perumahan yang layak.

c. Masyarakat memperoleh akses terhadap pelayanan kesehatan.

d. Masyarakat memperoleh akses terhadap pendidikan.

\section{Teknik pengumpulan data}

Dalam penelitian ini, teknik pengumpulan dilakukan dengan wawancara, observasi partisipatif studi dokumen dan studi kepustakaan.

a. Wawancara, yaitu dengan melakukan tanya jawab langsung kepada para informan penelitian. Jumlah informan yang akan diwawancara adalah 10 (sepuluh). Bentuk wawancara adalah wawancara semi structure yaitu telah dibuat terlebih dahulu daftar pertanyaan. Namun dari jawaban informan berkembang pertanyaanpertanyaan diluar daftar pertanyaan yang ada. Daftar pertanyaan untuk tiap informan berbedabeda sesuai dengan uraian tugas yang berkaitan dengan kedelapan elemen yang menjadi fokus dalam penelitian ini. Tahapan wawancara yang dilakukan yaitu pertama diawali dengan wawancara untuk mendapatkan informasi secara spesifik. Selanjutnya melakukan wawancara untuk mendapatkan fenomena menyangkut pengelolaan bisnis usaha tani terpadu di jalan boulevard Tondano. Setelah mendapatkan fenomena, kemudian melakukan kembali wawancara untuk menjawab pertanyaan penelitian.

b. Observasi, yaitu dengan melakukan pengamatan langsung. Observasi dilakukan untuk mengkonfirmasi hasil wawancara dengan para informan kunci, itulah yang dimaksud dengan triangulasi. Observasi dilakukan guna memperoleh data yang lebih mendekati kebenaran yaitu dengan membandingkan hasil wawancara dengan keadaan yang sebenarnya.

c. Studi dokumen yaitu dengan mengumpulkan dokumen-dokumen untuk membandingkan informasi dengan hasil observasi dan wawancara. Studi dokumentasi yaitu mengumpulkan dokumen dan data-data yang diperlukan dalam permasalahan penelitian lalu ditelaah secara intens sehingga dapat mendukung dan menambah kepercayaan dan pembuktian suatu kejadian. Dengan adanya studi dokumentasi maka hasil observasi dan wawancara akan lebih kredibel atau dapat dipercaya (Satori dan Komariah, 2011).

d. Studi kepustakaan yaitu dengan menghimpun dokumen, data, maupun informasi yang relevan dengan topik penelitian. Informasi tersebut diperoleh dari buku-buku ilmiah, laporan penelitian, jurnal, tesis, peraturan perundangundangan, sumber-sumber tertulis baik cetak maupun elektronik dan referensi lainnya yang berkaitan dengan objek yang diteliti. Studi kepustakaan berkaitan dengan kajian teoritis dan referensi lain yang berkaitan dengan nilai, budaya dan norma yang berkembang pada situasi sosial yang diteliti, selain itu studi kepustakaan sangat penting dalam melakukan penelitian, hal ini dikarenakan penelitian tidak akan lepas dari literatur-literatur Ilmiah (Sugiyono, 2014). Studi kepustakaan dilakukan guna mengkaji beberapa teori dasar yang relevan dengan masalah yang akan diteliti, mengkaji hasil penelitian terdahulu yang ada kaitannya dengan penelitian yang akan dilakukan, mencari informasi yang relevan dengan masalah yang akan diteliti, dan memperdalam pengetahuan penulis tentang masalah dan bidang yang akan diteliti.

\section{Teknik analisis data}

Menurut Zarkasi (2014) tujuan akhir analisis data kualitatif adalah memperoleh makna, menghasilkan pengertian-pengertian, konsep-konsep serta mengembangkan hipotesis atau teori baru. Analisis data kualitatif adalah proses mencari serta menyusun secara sistematis data yang diperoleh dari hasil wawancara, catatan lapangan, dan bahan-bahan lainnya sehingga mudah dipahami agar dapat diinformasikan kepada orang lain.

Miles dan Huberman (1984) dalam Sugiyono, (2008), mengemukakan bahwa aktivitas dalam analisis data kualitatif dilakukan secara interaktif dan berlangsung secara terus-menerus sampai tuntas, sehingga datanya jenuh. Ukuran kejenuhan data ditandai dengan tidak diperolehnya lagi data atau informasi baru. Aktivitas dalam analisis meliputi reduksi data (data reduction), penyajian data (data display), serta penarikan kesimpulan dan verifikasi (conclusion drawing/verification). Tahapan proses analisis data serta interaksinya adalah sebagai berikut:

1. Reduksi Data

Dari lokasi penelitian, data lapangan dituangkan dalam uraian laporan yang lengkap dan terinci. Data dan laporan lapangan kemudian 
direduksi, dirangkum, dan kemudian dipilah-pilah hal yang pokok, difokuskan untuk dipilih yang terpenting kemudian dicari tema atau polanya (melalui proses penyuntingan, pemberian kode dan pentabelan). Reduksi data dilakukan terus menerus selama proses penelitian berlangsung. Pada tahapan ini setelah data dipilah kemudian disederhanakan, data yang tidak diperlukan disortir agar memberi kemudahan dalam penampilan, penyajian, serta untuk menarik kesimpulan sementara.

\section{Penyajian Data}

Penyajian data (display data) dimasudkan agar lebih mempermudah bagi peneliti untuk dapat melihat gambaran secara keseluruhan atau bagian-bagian tertentu dari data penelitian. Hal ini merupakan pengorganisasian data kedalam suatu bentuk tertentu sehingga kelihatan jelas sosoknya lebih utuh. Data-data tersebut kemudian dipilah-pilah dan disisikan untuk disortir menurut kelompoknya dan disusun sesuai dengan katagori yang sejenis untuk ditampilkan agar selaras dengan permasalahan yang dihadapi, termasuk kesimpulan-kesimpulan sementara diperoleh pada waktu data direduksi.

\section{Penarikan Kesimpulan/Verifikasi}

Pada penelitian kualitatif, verifikasi data dilakukan secara terus menerus sepanjang proses penelitian dilakukan. Sejak pertama memasuki lapangan dan selama proses pengumpulan data, peneliti berusaha untuk menganalisis dan mencari makna dari data yang dikumpulkan, yaitu mencari pola tema, hubungan persamaan, hipotetsis dan selanjutnya dituangkan dalam bentuk kesimpulan yang masih bersifat tentatif.

\section{HASIL DAN PEMBAHASAN}

\section{Deskripsi Lokasi Penelitian}

Minahasa merupakan daerah dengan ketinggian rata-rata 591 meter diatas permukaan laut, terletak pada posisi 01001'00" - 01029'00" Lintang Utara dan 124034'00” - 125005'00" Bujur Timur. Luas wilayah Minahasa, adalah berupa daratan seluas 1.141,64 km2.

Akhir tahun 2018, wilayah administrasi Kabupaten Minahasa terdiri dari 25 wilayah kecamatan. Berdasarkan elevasi (ketinggian dari permukaan laut), dataran di Kabupaten Minahasa terdiri dari:
1. $0 \mathrm{~m}-100 \mathrm{~m}=8 \%$

2. $101 \mathrm{~m}-500 \mathrm{~m}=16 \%$

3. $501 \mathrm{~m}-1000 \mathrm{~m}=76 \%$

4. $1.001 \mathrm{~m}$ keatas $=0 \%$

Wilayah Kabupaten Minahasa bagian utara berbatasan dengan Laut Sulawesi, Kota Manado, dan Kota Tomohon, bagian timur berbatasan dengan Laut Maluku, Kabupaten Minahasa Utara, dan Kota Tomohon, bagian selatan berbatasan dengan Laut Maluku dan Kota Tomohon, dan bagian barat berbatasan dengan Kabupaten Minahasa Selatan dan Kota Tomohon.

Penduduk Kabupaten Minahasa berdasarkan proyeksi penduduk tahun 2018 sebanyak 338.364 jiwa yang terdiri atas 172.992 jiwa penduduk laki-laki dan 165.372 jiwa penduduk perempuan. Dibandingkan dengan jumlah penduduk tahun 2010, penduduk Minahasa mengalami pertumbuhan sebesar 9,02 persen. Sementara itu besarnya angka rasio jenis kelamin tahun 2018 penduduk laki-laki terhadap penduduk perempuan sebesar 104,61. Rasio jenis kelamin per kecamatan cukup beragam dengan rasio jenis kelamin tertinggi pada Kecamatan Lembean Timur sebesar 112,06 dan terendah pada Kecamatan Tondano Selatan sebesar 100,69.

Kepadatan penduduk di Kabupaten Minahasa tahun 2018 mencapai 296,38 jiwa/km2. Kepadatan Penduduk di 25 kecamatan cukup beragam dengan kepadatan penduduk tertinggi terletak di Kecamatan Langowan Timur dengan kepadatan sebesar 1.765,33 jiwa/km2 dan terendah di Kecamatan Kombi sebesar 82,80 jiwa/Km2.

\section{Demografi Informan Penelitian}

Demografi informan dikelompokkan kedalam empat kategori, yaitu: berdasarkan pendidikan, gender, usia dan pendapatan. Demografi informan dimaksud dijelaskan secara rinci sebagai berikut:

1. Informan Berdasarkan Pendidikan

Berdasarkan tingkat pendidikan, mayoritas informan berpendidikan Sekolah Menegah Atas (SMA) yaitu sebanyak 7 Informan atau $46.7 \%$ dari total informan. Sementara itu informan dengan tingkat pendidikan Sekolah Menegah Pertama (SMP) berjumlah 4 informan atau $26.7 \%$ dari total informan, informan dengan tingkat pendidikan Sekolah Dasar (SD) berjumlah 3 informan atau $20 \%$ dari total informan serta informan dengan tingkat pendidikan Strata Satu (S1) berjumlah 1 informan atau $6.7 \%$ dari total informan. Adapun sebaran pendidikan informan dimaksud ditunjukkan oleh gambar 1. 


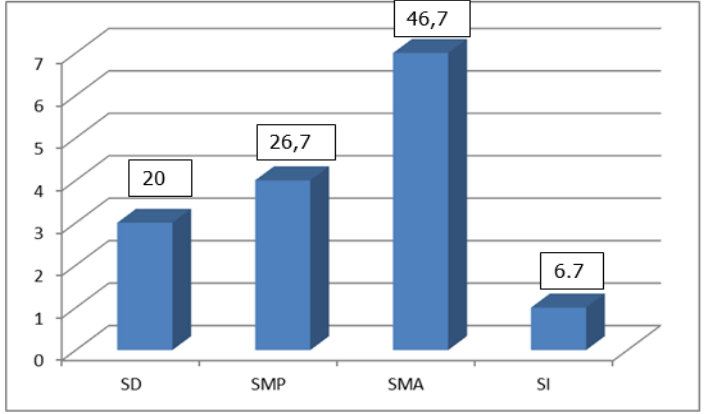

Gambar 1. Informan Berdasarkan Pendidikan

\section{Informan Berdasarkan Gender}

Berdasarkan gender, mayoritas sebaran informan dalam penelitian ini merupakan informan dengan gender laki-laki sebanyak 11 informan atau $73.33 \%$ dari total informan. Sedangkan informan dengan gender perempuan sebanyak 4 informan atau $26.67 \%$ dari total informan. Meskipun demikian, dapat diyakini bahwa isu gender tidak menjadi pengaruh terhadap jawaban informan dalam penelitian ini karena pertanyaan penelitian berlaku umum untuk kesemua gender. Sebaran informan berdasarkan gender dalam penelitian ini ditunjukan oleh gambar 2 .

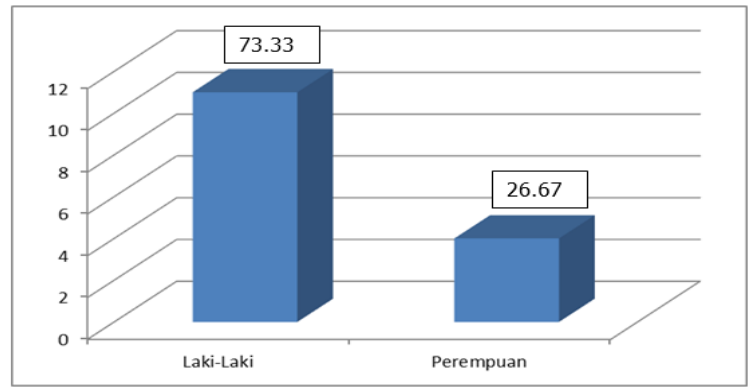

Gambar 2. Informan Berdasarkan Gender

\section{Informan Berdasarkan Usia}

Berdasarkan usia, mayoritas sebaran responden dalam penelitian ini merupakan informan dengan usia antara 41-50 tahun sebanyak 6 informan atau $40 \%$ dari total informan, informan dengan usia antara 31-40 tahun sebanyak 4 informan atau $26.67 \%$ dari total informan, informan dengan lebih dari 50 tahun sebanyak 3 informan atau $20 \%$ dari total informan dan informan dengan usia kurang dari 30 tahun sebanyak 2 informan atau $13.33 \%$ dari total informan. Meskipun demikian, dapat diyakini bahwa usia tidak menjadi pengaruh terhadap jawaban informan dalam penelitian ini karena pertanyaan penelitian berlaku umum untuk kesemua usia. Sebaran informan berdasarkan usia dalam penelitian ini ditunjukan oleh gambar 3 .

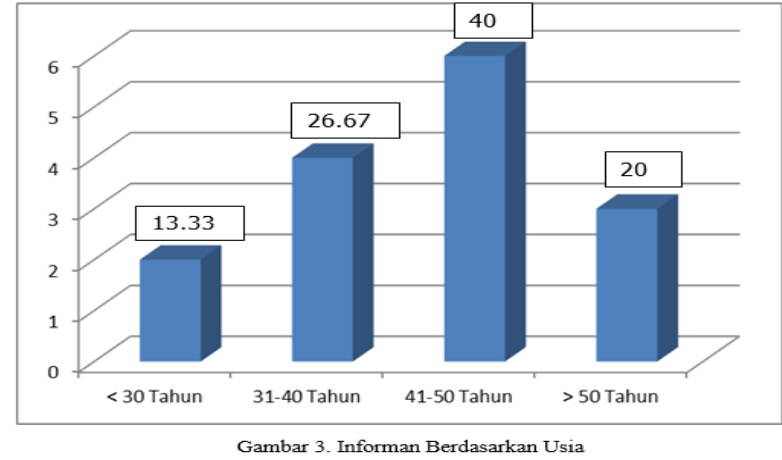

4. Informan Berdasarkan Pendapatan

Berdasarkan pendapatan, mayoritas sebaran informan dalam penelitian ini merupakan informan dengan pendapatan Rp.3.310.723 - Rp.5.000.000, yaitu sebanyak 6 informan atau $40 \%$ dari total informan. Sementara itu informan dengan pendapatan kurang dari Rp. 3.310.723 yaitu sebanyak 5 informan atau $33.33 \%$ dari total informan, selanjutnya informan dengan pendapatan Rp.5.000.000-Rp.10.000.000 yaitu sebanyak 3 informan atau $20 \%$ dari total informan dan informan dengan pendapatan lebih dari Rp.10.000.000 yaitu sebanyak 1 informan atau $6.67 \%$ dari total informan. Sebaran Informan berdasarkan pendapatan dimaksud ditunjukan gambar 4.

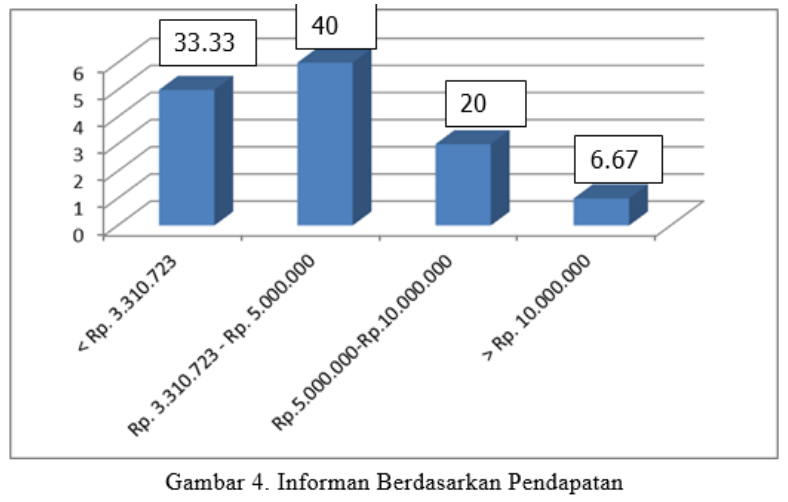

Hasil penelitian untuk mengetahui pengelolaan bisnis usahatani terpadu di jalan boulevard Tondano, maka dilakukan wawancara secara mendalam dengan 25 informan kunci Informan kunci yang diwawancarai yaitu petani, pengunjung dan pemerintah di Desa Koya Kecamatan Tondano Selatan.

Wawancara ini disesuaikan dengan fokus penelitian. Fokus penelitian ini adalah bagaimana pengelolaan bisnis usaha tani terpadu di jalan boulevard Tondano. Pengelolaan bisnis usaha tani terpadu yang dimaksud yaitu alih fungsi sebagian 
lahan pertanian menjadi tempat usaha tanpa beralih profesi sebagai petani, dikarenakan lahan pertanian yang dialih fungsikan hanya sebahagian kecil, jadi sebahagian besar lahan pertanian tetap berfungsi sebagai lahan persawahan. Bisnis usaha tani terpadu bertujuan untuk meningkatkan kesejahteraan petani. Keuntungan dari usahatani terpadu antara lain: 1) mampu meningkatkan pendapatan rumah tangga; 2) mengurangi risiko kegagalan panen; 3) memberikan tambahan lapangan kerja bagi keluarga; 4) meningkatkan efisiensi pengunaan sumberdaya; 5) dapat menyediakan pangan bagi keluarga; 6) meningkatkan produktivitas lahan; dan 7) memperbaiki kesejahteraan rumah tangga petani, kesejahteraan yang dimaksud yaitu :

a. Masyarakat dapat mencukup kebutuhan sandangnya.

b. Masyarakat bisa memperoleh perumahan yang layak.

c. Masyarakat memperoleh akses terhadap pelayanan kesehatan.

d. Masyarakat memperoleh akses terhadap pendidikan.

\section{Bisnis Usaha Tani Mampu Meningkatkan Pendapatan Rumah Tangga.}

Pertanyaan yang diajukan untuk mengetahui lebih lanjut apakah pengelolaan bisnis usahatani terpadu di jalan boulevard Tondano mampu untuk meningkatkan pendapatan rumah tangga petani. Dapat dilihat pada Tabel 1.

Tabel 1. Hasil Wawancara Ke-1

\section{Pertanyaan :}

Apakah pengelolaan bisnis usahatani terpadu di jalan

boulevard Tondano mampu untuk meningkatkan

pendapatan rumah tangga petani?

Informan 1:

"Ya kalo mo lia saat ini memang dengan ini torang pe usaha selain torang batanam padi kong torang ba piara ternak ya memang katu ada peningkatan pendapatan no. Karena dengan ada ini kuliner-kuliner di sepanjang jalan boulevard ini, torang pe ternak le torang boleh jual pa dorang for diolah jadi bahan makanan, jadi kita rasa katu ada peningkatan no tu pemasukan."

Kalau melihat saat ini menang dengan usaha yang kami miliki selain kami menanam padi dan memelihara ternak, kami memang mengalami peningkaatan pendapatan. Karena dengan adaya usaha-usaha kuliner di sepanjang jalan bolulevard, ternak yang kami pelihara bisa kami jual kepada para pengusaha kuliner untuk diolah menjadi bahan makanan, jadi saya rasa kami memiliki peningkatan pemasukan.

\begin{abstract}
Sambungan Tabel 1 Hasil Wawancara Ke-1:
Informan 3

"Sekarang katu lumayan noh torang pe pengahasilan, karena kita kwa pe sawah sebagian ada bekeng akang tampa makan, kong kita le ja ba piara bebek jadi kita syukuri noh kita pe penghasilan sekarang."

Saat ini penghasilan kami lumayan, karena sawah yang kami miliki sebagian lahanya dibuat tempat usaha rumah makan, selain itu saya juga memelihara ternak bebek jadi saya merasa bersyukur dengan penghasilan yang saya miliki sekarang.

Informan 15 :

"Karena kita rajin iko pelatihan yang pemerintah ja bekeng, kong kita terapkan pa ta pe lahan pertanian, kita rasa tu pendapatan petani so lebe baik sekarang. "

Karena saya rajin mengikuti pelatihan yang diadakan oleh pemerintah, dan saya terapkan pada saat pengelolaan lahan pertanian saya, saya rasa pendapatan pentane menjadi lebih baik saat ini
\end{abstract}

Tabel 1 menunjukkan bahwa pengelolaan bisnis usahatani terpadu di jalan boulevard Tondano pada umumnya membuat petani mampu untuk meningkatkan pendapatan sehingga dapat menghidupi keluarganya. Peningkatan pendapatan petani tidak saja hanya berasal dari hasil pertanian akan tetapi petani juga ada yang beternak serta menggunakan sebagian lahannya untuk tempat usaha, hal inilah yang mampu meningkatkan pendapatan petani yang memiliki lahan untuk usahatani di sepanjang jalan boulevard Tondano.

2. Bisnis Usaha Tani Mampu Mengurangi Risiko Kegagalan Panen.

Pertanyaan yang diajukan untuk mengetahui lebih lanjut apakah pengelolaan bisnis usahatani terpadu di jalan boulevard Tondano mampu untuk mengurangi resiko kegagalan panen. Hasil wawancara dapat dilihat pada Tabel 2 .

Tabel 2. Hasil Wawancara Ke-2

\section{Pertanyaan :}

Apakah pengelolaan bisnis usahatani terpadu di jalan

boulevard Tondano mampu untuk mengurangi resiko kegagalan panen?

\footnotetext{
Informan 1

"Gagal panen memang hal yang paling bekeng tako petani, makannya untuk mencegah kalo hal buruk terjadi torang katu musti pande-pande, salah satunya torang harus piara ternak supaya kalo nda minta-minta torang gagal panen, torang masih ada pendapatan laeng ",

Gagal panen merupakan hal yang paling membuat petani takut, makanya untuk mencegah kalau hal buruk ini terjadi kepada kami, kami musti pintar-pintar, salah satunya kami harus memelihara ternak, agar supaaya kalau hal yang tidak dimintaminta terjadi yaitu gaagal panen, kami masih memiliki pendapat lain.

Informan 2

Permasalahan gagal panen menang permasalahan yang sangat dikhawatirkan para petani, untuk itulah pentingnya pemberian penyuluhan-penyuluhan kepada para petani dengan tujuan mengurangi terjadinya gagal panen.
} 


\begin{abstract}
Sambungan Tabel 2 Hasil Wawancara Ke-2:
Informan 3

"Ini gagal panen memang paling bekeng tako petani, mar sekarang kwa resiko gagal panen so semakin kecil, karena ini teknologi pertanian so lebe canggih, keculi katu karena faktor alam. Dengan sekarang petani so banyak cara mo dapa penghasilan kita kase contoh rupa kita yang ja piara ternak, ini kan boleh mo tutupi tu kebutuhan-kebutuhan." Gagal panen ini memang hal yang paling membuat petani takut, tetapi sekarang resiko gagal panen semakin kecil, karena saat ini teknologi pertanian sudah semakin canggih, kecuaali gagal panen terjadi karena faktor alam. Dengan saat ini petani sudah memiliki banyak cara untuk mendapatkan penghasilan, contonya saya, saya memelihara ternak, kan ini bisa menutupi kebutuhan-kebutuhan hidup saya.
\end{abstract}

Tabel 2 menunjukkan bahwa umumnya petani sudah menyadari bahwa resiko gagal panen bisa saja terjadi, sehingga petani tidak hanya menggantungkan harapannya pada hasil pertanian tetapi juga lewat usaha lainnnya seperti beternak dan menggunakan sebagian lahan pertaniannya untuk tempat usaha seperti rumah makan, serta disewakan untuk dijadikan tempat usaha.

3. Bisnis Usaha Tani Mampu Memberikan Tambahan Lapangan Kerja Bagi Keluarga

Pertanyaan yang diajukan untuk mengetahui lebih lanjut apakah pengelolaan bisnis usahatani terpadu di jalan boulevard Tondano mampu untuk memberikan tambahan lapangan kerja bagi keluarga. Hasil wawancara dapat dilihat pada Tabel 3.

\section{Tabel 3. Hasil Wawancara Ke-3}

\section{Pertanyaan :}

Apakah pengelolaan bisnis usahatani terpadu di jalan boulevard Tondano mampu untuk memberikan tambahan lapangan kerja bagi keluarga?

\section{Informan 1}

"Tantu saja, kalo cuma ba batani padi, bisa cuma kita dengan meytua ja bantu-bantu, mar karena so dengan baternak, jadi so ja pangge keluarga laeng for baku bantu akang."

Tentu saja, kalau hanya menanam padi, bisa hanya istri saya saja yang membantu, namun karena sudah dengan beternak, jadi saya memanggil keluarga yang lain untuk bisa membantu saya.

\section{Informan 2}

Iya, karena sekarang kan petani sudah ada yang memelihara ternak dan bahkan ada yang sebagian lahannya diggunakan untuk tempat usaha kuliner, nah ini biasanya membuka lapangan pekerjaan khususnya untuk keluarga si petani itu, baik kakak-adik bahkan ada petani yang anaknya diikutsertakan untuk membantu usahannya.

Informan 3

"Oh iyo, karena kita kan selain batanam padi, kita ba rumah makan, nda mungkin kita dengan ta pe istri yang kerja samua, jadi kita pangge keluarga laeng terutama tu nda ada kerja kong baku-baku bantu dengan kita. Istilanya dang bagi-bagi berkat."

\section{Sambungan Tabel 3 Hasil Wawancara Ke-3:}

Iya, karena selain menanam padi, saya juga membuka rumah makan, jadi tidak mungkin hanya saya dan istri saya yang kerja semua pekerjaan, jadi saya menanggil keluarga yang lain terutama yang tidak memiliki pekerjaan untuk memantu saya. Istilahnya membagibagi berkat.

Tabel 3 menunjukkan bisnis usaha tani di jalan boulevard Tondano mampu untuk memberikan tambahan lapangan kerja bagi keluarga. Hal ini dikarenakan petani yang mengelolah lahan pertanian jika memerlukan tambahan tenaga kerja, mereka mengajak keluarga terdekatnya untuk membantu dalam mengelolah lahan dan ternaknya.

\section{Bisnis Usaha Tani Mampu Meningkatkan} Efisiensi Penggunaan Sumberdaya

Pertanyaan yang diajukan untuk mengetahui lebih lanjut apakah pengelolaan bisnis usahatani terpadu di jalan boulevard Tondano mampu untuk meningkatkan efisiensi pengunaan sumberdaya. Hasil wawancara dapat dilihat pada Tabel 4.

\section{Tabel 4. Hasil Wawancara Ke-4}

\section{Pertanyaan :}

Apakah pengelolaan bisnis usahatani terpadu di jalan boulevard Tondano mampu untuk meningkatkan efisiensi pengunaan sumberdaya?

Informan 1

Tentu saja, sumberdaya lahan dan sumberdaya manusia. Informan 2

Menurut saya iya, pengelolaan bisnis usahatani terpadu di jalan boulevard Tondano mampu untuk meningkatkan efisiensi pengunaan sumberdaya baik itu sumberdaya manusia maupun sumberdaya lahan.

\section{Informan 3}

"Menurut kita iyo, torang lia sekarang, selain katu tu lahan pake bertani, depe sebagian lahan dorang bekeng akang rumah-rumah makan, kan bagus for mo kase tingkatkan kesejahteraan."

Menurut saya iya, kita lihat sekarang, selain lahan untuk bertani, sebagian lahan diggunakan untuk dibuat rumah makan-rumah makan, itu bagus untuk meningkatkan kesejahteraan.

Tabel 4 menunjukkan bahwa pengelolaan bisnis usahatani terpadu di jalan boulevard Tondano mampu untuk meningkatkan efisiensi pengunaan sumberdaya, karena dengan memanfaatkan sumberdaya yang ada maka petani bisa meningkatkan pendapatannya. Sumberdaya yang dimanfaatkan petani baik lahan, air, mesin bahkan sumberdaya manusia yaitu pekerja yang membantu para petani untuk mengarap lahannya. 


\section{Bisnis Usaha Tani Dapat Memampukan Petani} Menyediakan Pangan Bagi Keluarga

Pertanyaan yang diajukan untuk mengetahui lebih lanjut apakah pengelolaan bisnis usahatani terpadu di jalan boulevard Tondano menjadikan petani mampu untuk menyediakan pangan bagi keluarga.

\section{Tabel 5. Hasil Wawancara Ke-5}

$$
\text { Pertanyaan : }
$$

Apakah pengelolaan bisnis usahatani terpadu di jalan boulevard Tondano mampu membuat petani menyediakan pagan bagi keluarganya?

Informan 1

"Sama dengan yang kita bilang tadi bahwa torang pe usaha selain torang batanam padi kong torang juga ba piara ternak, makanya torang selalu ada saja pendapatan khususnya for mo sadia akang pangan for tong pe keluarga."

Sama seperti yang saya katakan tadi bahwa selain menanam padi kami juga memelihara ternak, makanya kami selalu ada saja pendapatan, khususnya untuk menyediakan pangan bagi keluarga kami.

Informan 2

Tentu saja, kan petani mendapatkan pendapatan dari usahatani yang dia lakukan, maka secara otomatis petani itu akan mampu untuk menyediakan pangan bagi keluargannya.

Informan 3

Bersyukur banyak sampai saat ini kita masih bisa menyediakan makanan yang cukup bagi keluarga.

Tabel 5 menunjukkan bahwa pengelolaan bisnis usahatani terpadu di jalan boulevard Tondano mampu membuat petani menyediakan pagan bagi keluarganya. Petani merasa pendapatannya cukup sehingga mereka mampu untuk memenuhi kebutuhan pangan bagi keluarganya.

\section{Bisnis Usaha Tani Mampu Meningkatkan Produktifitas Lahan}

Pertanyaan yang diajukan untuk mengetahui lebih lanjut apakah pengelolaan bisnis usahatani terpadu di jalan boulevard Tondano mampu untuk meningkatkan produktivitas lahan. Hasil wawancara dapat dilihat pada Tabel 6 .

Tabel 6. Hasil Wawancara Ke-6

\section{Pertanyaan :}

Apakah pengelolaan bisnis usahatani terpadu di jalan boulevard Tondano mampu untuk meningkatkan produktivitas lahan?

\section{Informan 1}

"Sekarang kan dinas pertanian ada dorang pe penyuluh lapangan, nah kalo torang petani iko bae-bae tu apa yang penyuluh ja ajarkan pa torang, depe hasil torang mampu katu mo tingkatkan tu hasil dari torang pe lahan."

Sekarang dinas pertanian memiliki penyuluh lapangan, nah kalau kita petani mengikuti dengan baik apa yang diajarkan penyuluh, hasilnya kita akan mampu meningkatkan hasil pertanian dari lahan pertanian yang kita miliki.

\begin{abstract}
Sambungan Tabel 6 Hasil Wawancara Ke-6:
Informan 2:

Peningkatan produktivitas lahan semuanya tergantung dari kesungguhan para petani untuk mengusahakan lahannya. Jika petani berusaha udan bekerja keras tentunya hasil pertanian dan peteranakannya akan meningkat, berbeda jika petani yang tidak mengusahakan lahanya dengan giat, tentu hasil yang didapat tidak akan sebesar hasil yang didapat petani yang bekerja dengan giat.

Informan 3

"Iya, karena sekarang torang banyak diberikan bantuan bibit-bibit unggul sehingga kita rasa torang so mulai mengalami peningkatan hasil."

Iya, karena sekarang kita banyak memiliki bibit-bibit unggul, sehingga saya rasa kita sudah mulai mengalami peningkatan hasil.
\end{abstract}

Tabel 6 menunjukkan bahwa pengelolaan bisnis usahatani terpadu di jalan boulevard Tondano mampu untuk meningkatkan produktivitas lahan, hal ini dibuktikan dengan semakin meningkatnya hasil dari lahan yang dikelolah oleh para petani.

\section{Bisnis Usaha Tani Mampu Memperbaiki} Kesejahteraan Rumah Tangga Petani.

Pertanyaan yang diajukan untuk mengetahui lebih lanjut apakah pengelolaan bisnis usahatani terpadu di jalan boulevard Tondano mampu untuk memperbaiki kesejahteraan rumah tangga petani, kesejahteraan. Hasil wawancara dapat dilihat pada Tabel 7.

\section{Tabel 7. Hasil Wawancara Ke-7}

Pertanyaan :

Apakah pengelolaan bisnis usahatani terpadu di jalan boulevard Tondano mampu untuk memperbaiki kesejahteraan rumah tangga petani?

kesejahteraan yang dimaksud yaitu :

a. Masyarakat dapat mencukup kebutuhan sandangnya. b. Masyarakat bisa memperoleh perumahan yang layak.

c. Masyarakat memperoleh akses terhadap pelayanan kesehatan.

d. Masyarakat memperoleh akses terhadap pendidikan. Informan 1

"Dari dulu sampe sekarang kita pe pekerjaan kan cuma batani, tapi kita rasa kita pe pengahsilan cukup untuk sandang, rumah, for ongkos tu kesehatan dengan kita mampu kase sekolah kita pe anak".

Dari dahulu sampe sekarang pekerjaan saya kan hanya bertani, tetapi saya rasa penghasilan saya cukup untuk sangang, rumah, buat membiayai kesehatan dan mampu menyekolahkan anak.

\section{Informan 2}

Kalau dari pengamatan saya, petani sekarang sudah cukup sejahtera, bahkan di lingkungan sekitar tempat kerja saya, banyak petani yang sudah memiliki rumah bagus dan bahkan ada kendaraan roda empat dan roda dua. Jadi kalau ditanyakan apa mamu mencukui kebutuhan sandang, perumahan yang layak, akses terhadap pelayanan dan kesehatan serta pendidikan saya rasa jawabannya ya. 


\begin{abstract}
Sambungan Tabel 7 Hasil Wawancara Ke-7:
Informan 3

"Karena torang pe penghasilan semakin baik, kita rasa kita katu biar mo bilang nda sejahtera-sejahtra sekali atau so berkelebihan sekali, tapi intinya kita boleh se bapake ta pe keluarga, kase rumah yang dorang nyaman mo tinggal akang dengan tantu kase sekolah tu anak-anak."

Karena penghasilan kami semakin baik, saya rasa untuk dibilang sejahtera atau berkelebihan sekali tidak, tetapi intinya saya boleh memberikan paakaian yang layak untuk keluarga, memberikan rumah yang laying untuk mereka tinggalo dan tunya mampu menyekolahkan anak-anak.
\end{abstract}

Tabel 7 menunjukkan bahwa pengelolaan bisnis usahatani terpadu di jalan boulevard Tondano mampu untuk memperbaiki kesejahteraan rumah tangga petani hal ini dibuktikan dengan umumnya petani mampu untuk mencukupi kebutuhan sandangnya, menempati perumahan yang layak, memperoleh akses terhadap pelayanan kesehatan serta memperoleh akses terhadap pendidikan.

\section{KESIMPULAN DAN SARAN}

\section{Kesimpulan}

Hasil penelitian diperoleh kesimpulan bahwa pengelolaan bisnis usahatani terpadu di jalan boulevard Tondano sudah cukup optimal. Hal ini disebabkan karena:

1. Pengelolaan bisnis usahatani terpadu di jalan boulevard Tondano mampu untuk meningkatkan pendapatan rumah tangga petani. Petani melakukan usahatani lewat menanam padi, ada juga yang memelihara ternak dan ada petani yang menggunakan sebagian lahannya untuk membuka usaha rumah makan, ataupun menyewakan sebagian lahan pertaniannya untuk dijadikan rumah makan.

2. Pengelolaan bisnis usahatani terpadu di jalan boulevard Tondano mampu mengurangi resiko kegagalan panen. Lewat berbagai usaha seperti beternak, menggunakan sebagian lahan untuk tenpat usaha serta menyewakan sebagian lahan sebagai tempat usaha maka akan dapat mengurangi resiko tidak adanya penghasilan ketika terjadi gagal panen.

3. Pengelolaan bisnis usahatani terpadu di jalan boulevard Tondano mampu memberikan tambahan lapangan kerja bagi keluarga petani. Petani yang memiliki lahan pertanian di jalan boulevard Tondano umumnya selain menjadi petani yang mengurusi sawah mereka juga memiliki tambahan usaha lain seperti beternak dan menggunakan sebagian lahan yang mereka punya sebagai tempat usaha seperti rumah makan. Dengan memiliki usaha sampingan otomatis akan tercipta lapangan pekerjaan. Umumnya para petani memberikan pekerjaan kepada keluarganya, karena mereka akan lebih mudah berkomunikasi serta percaya dengan keluargannya sendiri dalam membantu mengelola usahanya.

4. Pengelolaan bisnis usahatani terpadu di jalan boulevard Tondano mampu meningkatkan efisiensi penggunaan sumberdaya. Petani yang memanfaatkan semua sumberdaya yang ada baik, tenaga, mesin maupun air yang membuat tanaman padi yang ditanam akan menghasilkan padi yang berkualitas.

5. Pengelolaan bisnis usahatani terpadu di jalan boulevard Tondano dapat memampukan petani menyediakan pangan bagi keluarga. Petani yang memiliki lahan pertanian di jalan boulevard Tondano umumnya memiliki pendapatan yang cukup sehingga mampu untuk menyediakan pangan bagi keluargannya.

6. Dengan pengelolaan bisnis usahatani terpadu di jalan boulevard Tondano mampu meningkatkan produktifitas lahan. Peningkatan produktivitas lahan merupakan tanda bahwa petani sudah mampu mengelola lahan pertaniannya. Dengan semakin meningkatnya produktifitas lahan maka pendapatan petani pun akan semakin meningkat yang secara otomatis akan menakian tingkat kesejahtraan petani.

7. Dengan pengelolaan bisnis usahatani terpadu di jalan boulevard Tondano mampu memperbaiki kesejahteraan rumah tangga petani. Kesejahtraan petani ditandai dengan kemampuan untuk memenuhi kebutuhan sandangnya, kemampuan untuk memperoleh perumahan yang layak, kemampuan akan akses terhadap pelayanan kesehatan, serta kemampuan memperoleh akses terhadap pendidikan.

\section{Saran}

Dari hasil penelitian ini disarankan agar :

1. Bagi para petani agar lebih rajin mengikuti penyuluhan-penyuluhan yang diberikan oleh pemerintah melalui para penyuluh-penyuluh pertanian, karena penyuluhan yang diberikan 
oleh para penyuluh pertanian merupakan materi-materi yang bermanfaat untuk menambah wawasan para petani mengenai pemanfaatan teknologi pertanian untuk pengelolaan lahan pertanian, penggunaan bibitbibit tanaman yang cocok dengan karakteristik lahan yang diolah oleh para petani, sehingga petani dapat mempraktekan ilmu-ilmu yang didapat dalam pengelolaan lahan pertanian dalam rangka meningkatkan produksi hasil pertanian.

2. Bagi para penyuluh dari pemerintah kiranya selalu menambahkan materi penyuluhan, agar para penyuluh lebih bisa menyampaikan informasi terbaru tentang metode-metode terbaru dalam bertani, penggunaan alat-alat baru yang memudahkan para petani untuk bekerja serta cara-cara menamam padi guna untuk peningkatan produksi hasil pertanian.

3. Diharapkan kepada pemerintahan agar dapat lebih memperhatinkan para petani yang memiliki lahan di Jalan Boulevard Tondano khususnya dan petani pada umumnya dengan jalan mendirikan suatu lembaga atau koperasi agar perani akan lebih mudah baik memperoleh informasi mengenai teknik-teknik dalam pertanian, cara-cara penjualan hasil pertanian, serta petani akan lebih mudah memperoleh akses untuk pinjaman modal pertanian.

\section{DAFTAR PUSTAKA}

Creswell, J. W. 2003. Research Design Qualitative \& Quantitative Approaches. USA : SAGE Publications,Inc.

Kirk, J. and Miller, M.I. 1986. Reability and Validity in Qualitative Research, Vol.1, Beverly Hills: Sage Publication.
Moleong, L. 2004. Metodologi Penelitian Kualitatif. Bandung: PT. Remaja Rosdakarya.

Muhajir, N. 2000. Metodologi Penelitian Kualitatif. edisi IV. Yogyakarta : Rake Sarasin.

Saroinsong D., Panelewen, V. V. J, Laoh, O. E. H., dan Pakasi C. B. D., 2012. Agribisnis Tanaman Stroberi Di Desa Rurukan Kecamatan Tomohon Timur. Eugenia Volume 18 No. 3 Desember 2012.

Satori, D., dan Komariah, A., 2011. Metodologi Penelitian Kualitatif. Bandung: Penerbit Alfabeta.

Sugiyono, 2008. Metode Penelitian Administrasi. Bandung : Alfabeta.

Sugiyono, 2014. Metode Penelitian Kuantitatif Kualitatif dan R\&D. Bandung: Alfabeta.

Sugiyono. 2009. Metode Penelitian Kuantitaif Kualitatif dan R\&D. Alfabeta : Bandung.

Winoto J. 2005. Kebijakan Pengendalian Alih Fungsi Tanah Pertanian dan Implementasinya. Prosiding Seminar Penanganan Konversi Lahan dan Pencapaian Pertanian Abadi. Satyawan et al. Pusat Studi Pembangunan Pertanian dan Pedesaan LPPM-IPB, Bogor.

Zarkasi, A., 2014. Analisis Data Penelitian Kualitatif. STAI Negeri Palangka Raya. Palangka Raya. http://ahmadzarkasyiblog.blogspot.co.id/2014/01/ analisis-datapenelitian-kualitatif.html. 